\title{
Pengaruh Ukuran Perusahaan dan Leverage terhadap Nilai Perusahaan dengan Profitabilitas sebagai Variabel Intervening
}

\author{
Ayu Octaviany ${ }^{1}$, Syamsul Hidayat ${ }^{2}$, Miftahudin $^{3}$ \\ ${ }^{123}$ Universitas Bina Bangsa Banten
}

\begin{abstract}
The company is basically established to create added value, especially in generating profits. But in general the company is not only oriented towards achieving maximum profit, but also trying to increase the value of the company and the prosperity of its owners by maximizing stock prices. High stock prices make the value of the company also high and increase market confidence in the company's prospects in the future. Company value can be influenced by several factors, including Company Size, Leverage and Profitability. The purpose of this study was to determine the effect of Company Size, Leverage and Profitability on Company Value and to determine the effect of Company Size and Leverage on Company Value through Profitability. The data analysis technique used is the Partial Least Square (PLS) model. Sampling was taken using purposive sample method. A total of 8 Food and Beverage manufacturing companies in the 2013-2017 period were sampled. The results of this study indicate that Company Size has a significant effect on Profitability but has no effect on Company Value. Leverage has no significant effect on Company Value but has a significant effect on Company Value. Profitability is able to mediate the influence of firm size on company value. But profitability is not able to mediate the influence of leverage on Company Value.
\end{abstract}

Keywords : Leverage, Firm Value, Profitability, Firm Size

Abstrak

Perusahaan pada dasarnya didirikan guna menciptakan nilai tambah, terutama dalam menghasilkan laba. Namun pada umumnya perusahaan tidak hanya berorientasi pada pencapaian laba maksimal, tetapi juga berusaha meningkatkan nilai perusahaan dan kemakmuran pemiliknya dengan cara memaksimalkan harga saham. Harga saham yang tinggi membuat nilai perusahaan juga tinggi dan meningkatkan kepercayaan pasar pada prospek perusahaan dimasa mendatang. Nilai perusahaan dapat dipengaruhi oleh beberapa faktor, diantaranya Ukuran Perusahaan, Leverage dan Profitabilitas. Tujuan penelitian ini adalah untuk mengetahui pengaruh Ukuran Perusahaan, Leverage dan Profitabilitas terhadap Nilai Perusahaan serta mengetahui pengaruh Ukuran Perusahan dan Leverage terhadap Nilai Perusahaan melalui Profitbilitas. Teknik analisis data yang digunakan adalah model Partial Least Square (PLS). Pengambilian sampel diambil menggunakan metode purposive sample. Sebanyak 8 perusahaan manufaktur perusahaan Food and Beverage periode 2013-2017 dijadikan sampel. Hasil dari penelitian ini menunjukan bahwa Ukuran Perusahaan berpengaruh signfikan terhadap Profitabilitas namun tidak berpengaruh terhadap Nilai Perusahaan. Leverage tidak berpengaruh signifikan terhadap Nilai Perusahaan namun berpengaruh signifikan terhadap Nilai Perusahaan. Profitabilitas mampu memediasi pengaruh ukuran perusahaan terhadap nilai perusahaan. Namun profitbilitas tidak mampu memediasi pengaruh leverage terhadap Nilai Perusahaan.

Kata Kunci : Leverage, Nilai Perusahaan, Profitabilitas, Ukuran Perusahaan

\section{PENDAHULUAN}

Pesatnya ekonomi global saat ini menimbulkan ketatnya persaingaan usaha yang memiliki keunggulan tersendiri. Perusahaan pada dasarnya didirikan guna menciptakan nilai tambah, terutama dalam menghasilkan laba. Perusahaan yang menerapkan prinsip-prinsip ekonomi, umumnya tidak hanya berorientasi pada pencapaian laba maksimal, tetapi juga berusaha meningkatkan nilai perusahaan dan kemakmuran pemiliknya serta meningkatkan kepercayaan pasar pada prospek perusahaan dimasa mendatang.

Tujuan perusahaan dalam memaksimalkan nilai perusahaan adalah memaksimalkan harga saham. Tercapai tidaknya tujuan perusahaan dapat dilihat dan diukur dari harga saham perusahaan yang bersangkutan dari waktu ke waktu (Kasmir, 2012). Semakin tinggi harga saham, maka semakin tinggi nilai perusahaannya. Perusahaan yang memiliki nilai perusahaan tinggi akan menumbuhkan rasa kepercayaan dari pihak-pihak yang terkait dengan perusahaan tersebut maupun dari masyarakat luas. Hal ini disebabkan karena nilai perusahaan yang tinggi menunjukkan bahwa kinerja perusahaan yang baik. (Putri, 2012)

Dalam penelitian ini indikator yang digunakan untuk mengukur nilai perusahaan adalah Price Book of Value (PBV). PBV atau rasio per nilai 
buku yang merupakan perbandingan antara harga suatu saham dengan nilai buku. Menurut Sartono (2010:487) rasio harga saham terhadap nilai perusahaan atau PBV, menunjukan tingkat kemampuan perusahaan menciptakan nilai relatif terhadap jumlah modal yang diinvestasikan. Menurut Sartono (2010) dalam Alfi (2017), rasio harga saham terhadap nilai perusahaan atau PBV, menunjukan tingkat kemampuan perusahaan menciptakan nilai relatif terhadap jumlah modal yang diinvestasikan. PBV yang tinggi mencerminkan harga saham yang tinggi dibandikan nilai buku per - lembar pemegang saham.

Terdapat banyak faktor-faktor yang dapat menentukan nilai perusahaan, antara lain ukuran perusahaaan, leverage dan profitabilitas. Ukuran perusahaan dianggap mampu mempengaruhi nilai perusahaan. Karena semakin besar ukuran atau skala perusahaan maka akan semakin mudah pula perusahaan memperoleh sumber pendanaan baik yang bersifat internal maupun eksternal. Ukuran perusahaan merupakan cerminan dari asset yang dimiliki suatu perusahaan. Perusahaan yang memiliki ukuran yang lebih besar mempunyai pengaruh terhadap peningkatan profitabilitas dan nilai perusahaan (Setiadewi dan Purbawangsa, 2015) Selain itu perusahaan besar mempunyai lebih banyak sumber untuk meningkatkan nilai perusahaan karena memiliki akses yang lebih baik terhadap sumber-sumber pendanaan dari eksternal dibandingkan perusahaan kecil. (Hery, 2017).

Adapun penelitian yang dilakukan oleh Istamarwati dan Suseno (2017) yang menyatakan bahwa ukuran perusahaan berpengaruh positif dan signifikan terhadap nilai perusahaan. Namun penelitian yang dilakukan oleh Limbong dan Chabachib (2016) memiliki hasil yang bertentangan, dimana hasil penelitiannya menyatakan bahwa ukuran perusahaan memiliki pengaruh negatif dan tidak signifikan terhadap nilai perusahaan yang di proksikan dengan variabel price to book value (PBV).

Faktor lain yang dapat mempengaruhi nilai perusahaan adalah leverage. Sumber pendanaan dalam perusahaan dapat diperoleh dari internal perusahaan yang berupa laba ditahan (retained earning) dan penyusutan (depreciation) dan dari eksternal perusahaan yang berupa hutang atau penerbitan saham baru. Leverage menunjukan kemampuan dari suatu perusahaan untuk memenuhi segala kewajiban finansial dari perusahaan tersebut seandainya perusahaan tersebut dilikuidasi. (Pratamana dan Wiksuana, 2016). Menurut Ernawati dan Widyawati (2015) Leverage yang semakin besar menunjukkan resiko investasi yang semakin besar pula. Perusahaan dengan rasio leverage yang rendah memiliki resiko leverage yang lebih kecil. Dengan tingginya rasio leverage menunjukkan bahwa perusahaan tidak solvabel, artinya total hutangnya lebih besar dibandingkan dengan total asetnya. Adapun penelitian yang dilakukan oleh Setiadewi dan Purbawangsa (2015) menemukan bahwa leverage berpengaruh positif secara signifikan terhadap nilai perusahaan. Begitu pula dengan penelitian yang dilakukan oleh Cheng dan Tzeng (2011) yang menyatakan bahwa leverage berpengaruh positif terhadap nilai perusahaan. Sedangkan penelitian yang dilakukan oleh Ernawati dan Widyawati (2015) yang menyatakan bahwa leverage berpengaruh negatif dan signifikan terhadap nilai perusahaan.

Nilai perusahaan dapat di pengaruhi oleh profitabilitas. Profitabilitas perusahaan yang tinggi akan mencerminkan prospek perusahaan yang baik. Semakin tinggi profitabilitas yang dimiliki oleh suatu perusahaan, maka akan mencerminkan tingkat efisiensi perusahaan yang tinggi juga, sehingga terlihat kinerja perusahaan yang baik pula (Prataman dan Wiksuana, 2016). Penelitian yang dilakukan oleh Istamarwati dan Suseno (2017) menyatakan bahwa profitabilitas berpengaruh positif signifikan terhadap nilai perusahaan. Pernyataan tersebut di dukung oleh beberapa peneliti seperti Firmansyah dan Suwitho (2017) yang menyatakan profitabilitas berpengaruh positif terhadap nilai perusahaan. Hal ini disebabkan karena perusahaan yang memiliki kinerja dan manajemen yang baik dalam perusahaan sehingga memiliki tingkat profitabilitas yang terus meningkat setiap tahunnya. Sehingga para investor semakin tertartik untuk berinvestasi pada perusahaan yang memiliki profitabilitas yang tinggi (Arif Firmansyah dan Suwitho, 2017).

Berdasarkan uraian latar belakang dan research gap dari penelitian sebelumnya, maka dibuat rumusan masalah sebagai berikut :

1. Apakah Ukuran Perusahan berpengaruh signifikan terhadap Profiabilitas?

2. Apakah Leverage berpengaruh signifikan terhadap Profitabilitas?

3. Apakah Profitabilitas berpengaruh signifikan terhadap Nilai Perusahaan?

4. Apakah Ukuran Perusahaan berpengaruh signifikan terhadap Nilai Perusahaan?;

5. Apakah Leverage berpengaruh signifikan terhadap Nilai Perusahaan?

6. Apakah Ukuran perusahaan berpengaruh signifikan terhadap nilai Perusahaan melalui profitabilitas?

7. Apakah Leverage berpengaruh signifikan terhadap Nilai Perusahaan yang melalui Profitabilitas?

\section{KAJIAN LITERATUR}

\section{Nilai Perusahaan}

Variabel penelitian yang kedudukannya sebagai variabel endogen adalah nilai perusahaan. Menurut Brigham dan Houston (2011) Nilai perusahaan merupakan harga yang bersedia dibayar 
oleh calon pembeli apabila perusahaan tersebut dijual. Nilai perusahaan sering dikaitkan dengan harga saham. Semakin tinggi harga saham maka semakin tinggi pula nilai perusahaan.Nilai perusahaan diproksikan dengan Price Book of Value (PBV) dengan rumus :

\section{PBV : $\frac{\text { HargaSaham/lembar }}{\text { Nilai Buku ekuitas/lembar }}$}

\section{Ukuran Perusahaan}

Variabel penelitian yang kedudukannya sebagai variabel eksogen pertama adalah ukuran perusahaan. Ukuran Perusahaan Menurut Riyanto (2001) Ukuran perusahaan (Firm Size) merupakan menggambarkan besar kecilnya suatu perusahaan yang ditunjukan pada total aktiva, jumlah penjualan, rata-rata penjualan dan total aktiva.Ukuran perusahaan diproksikan oleh Ln (total asset) dengan rumus :

\section{SIZE = Ln (Total Asset $)$}

\section{Leverage}

Variabel penelitian yang kedudukannya sebagai variabel eksogen kedua (X2) adalah leverage. Menurut Irham Fahmi (2015) leverage adalah "rasio yang mengukur seberapa besar perusahaan dibiayai dengan utang. Penggunaan utang yang terlalu tinggi akan membahayakan perusahaan karena perusahaan akan masuk dalam kategori extreme leverage (utang ekstrim) yaitu perusahaan terjebak dalam tingkat utang yang tinggi dan sulit untuk melepaskan beban utang tersebut. Leverage diproksikan DebtEquity Ratio (DER) dengan rumus:

$$
\text { Debt to Equity Ratio }=\frac{\text { Total Utang }(\text { Debt })}{\text { Total Ekuitas }}
$$

\section{Profitabilitas}

Variabel penelitian yang kedudukannya sebagai variabel intervening adalah profitabilitas. Menurut Kasmir (2015 : 196) Profitabilitas adalah rasio untuk menilai kemampuan perusahaan dalam mencari keuntungan. Profitabilitas diproksikan dengan Return on Asset (ROA) dengan rumus :

$$
\text { ROA }=\frac{\text { laba bersih }}{\text { total aktiva }} \times 100 \%
$$

\section{Kerangka Konseptual}

Berdasarkan pemaparan diatas, maka terdapat kerangka koseptual dalam penelitian ini adalah sebagai berikut :

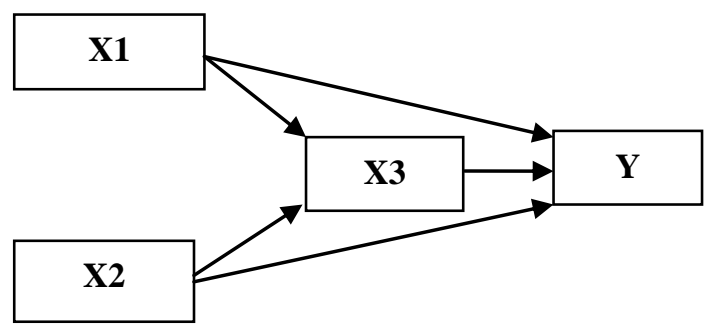

\section{Gambar Model Kerangka Konseptual}

H1 :Ukuran Perusahaan berpengaruh signifikan terhadap profitabilitas

H2 :Leverage berpengaruh signifikan terhadap profitabilitas

H3 :Profitabilitas bepengaruh signifikan terhadap nilai perusahaan.

H4 :Ukuran Perusahaan bepengaruh signifikan trehadap nilai perusahaan.

H5 :Leverage berpengharuh signifikan terhadap nilai perusahaan

H6 :Profitabilitas memediasi pengaruh ukuran perusahaan terhadap nilai perusahaan

H7 :Profitabiloitas memediasi pengaruh leverage terhadap nilai perusahaan.

\section{METODE PENELITIIAN}

Jenis penelitian yang digunakan dalam penelitian ini adalah penelitian kuantitatif dengan menggunakan model analisis jalur (path analysis). Metode penelitian ini adalah asosiatif yang menggunakan 2 variabel bebas, 1 variabel terikat dan 1 variabel intervening. Sumber data yang digunakan menggunakan data sekunder dan kuantitatif. Dalam penelitian ini pengumpulan data yaitu dilakukan dengan kepustakaan dan manual. Data yang dipergunakan dalam penelitian ini diperoleh dari IDX Statistic dan Indonesian Capital Market Directory tahun 2013-2017 Populasi target penelitian ini adalah perusahaan di Sektor Industri Barang Konsumsi yang telah terdaftar di BEI pada periode tahun 2013-2017 yang berjumlah sebanyak 40 perusahaan. Sedangkan populasi terjangkau nya adalah perusahaan sub sektor food and beverage periode tahun 2013 - 2017 yang berjumlah 18 perusahaan. Analisis data menggunakan metode Partial Least Square (PLS) dengan bantuan program SmartPLS 3.

\section{HASIL PENELITIAN DAN PEMBAHASAN}

\section{Evaluasi Outer (Model Pengukuran)}

Dari hasil analisa dengan menjalankan calculate-PLS algorithm diperoleh hasil seperti pada gambar berikut : 


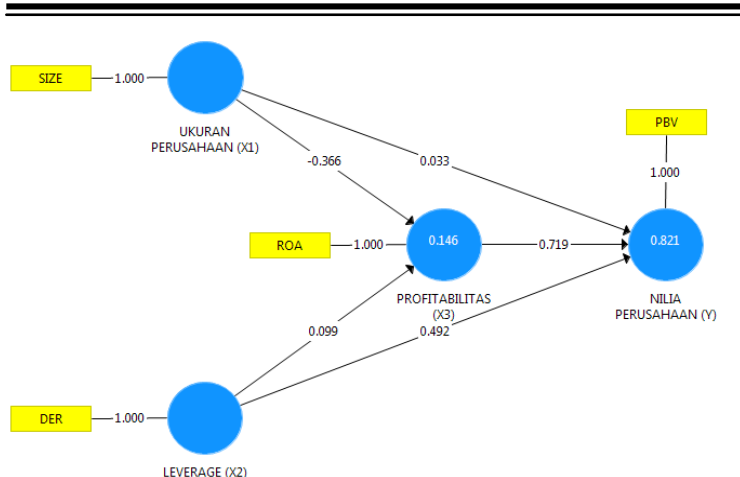

Gambar Model awal untuk perhitungan Algoritma PLS

Loading faktor menggambarkan seberapa besar keterkaitan indikator-indikator terhadap masing-masing konstruknya. Diagram jalur di atas menunjukkan bahwa semua indikator memiliki loading factor 1.000 yang berarti bahwa semua indikator sudah valid karena nilai loading factor memenuhi kriteria yaitu nilai loading factor konstruk harus diatas 0.70 . Hasil ini menunjukkan adanya keterkaitan yang baik antara indikatorindikator dengan masing-masing konstruk.

\section{Evaluasi Inner Model (Model Struktural)}

Melakukan evaluasi struktural (inner model) yang meliputi R-Square, goodness of fit dan path coefficient. Hasil dari pengujian inner model adalah sebagai berikut :

Tabel R-Square $\left(\mathbf{R}^{2}\right)$

\begin{tabular}{|c|c|}
\hline Konstruk & Nilai $\mathbf{R}^{2}$ \\
\hline Nilai Perusahaan & 0,821 \\
\hline Profitabilitas & 0,146 \\
\hline
\end{tabular}
sebagai berikut:

Nilai Perusahaan

Nilai R-Square variabel laten Nilai Perusahaan adalah 0,821 , hal ini menunjukan bahwa ukuran perusahaan (X1), leverage (X2) dan Profitabilitas (X3) dapat menjelaskan nilai perusahaan (Y) sebesar $82,1 \%$. Selebihnya atau sebesar 17,9 \% dijelaskan oleh variabel lain yang tidak dalam penelitian ini.

Profitabilitas

Nilai R-Square variabel laten profitabilitas adalah 0,146 , hal ini menunjukan bahwa ukuran perusahaan (X1) dan leverage (X2) dapat menjelaskan profitabilitas sebesar 14,6 \%. Selebihnya atau sebesar $85,4 \%$ dijelaskan oleh variabel lainnya.

Penilaian goodness of fit diketahui dari nilai $Q$-Square. Semakin tinggi $Q$-Square, maka model dapat dikatakan semakin baik atau semakin fit dengan data. Adapun hasil perhitngan nilai $Q$ Square adalah sebagai berikut :

$$
\begin{aligned}
Q \text {-Square } & =1-\left[\left(1-\mathrm{R}^{2} 1\right)\left(1-\mathrm{R}^{2} 2\right)\right. \\
& =1-[(1-0,821)(1-0,146)] \\
& =1-[(0,179)(0,854)]
\end{aligned}
$$

$$
\begin{aligned}
& =1-0,153 \\
& =0,847
\end{aligned}
$$

Berdasarkan hasil perhitungan di atas, diperoleh nilai $Q$-Square sebesar 0,799. Hasil ini mendekati angka 1 (satu) yang atinya dari hasil tersebut maka model penelitian ini dapat dinyatakan telah memiliki goodness of fit yang baik.

\begin{tabular}{cccc}
\hline \multicolumn{4}{c}{ Tabel Path Coefficient } \\
\hline & $($ O) & $\begin{array}{c}\text { T- } \\
\text { Statistics }\end{array}$ & $\begin{array}{c}\text { P } \\
\text { Values }\end{array}$ \\
\hline$(\mathrm{X} 2) \rightarrow(\mathrm{Y})$ & 0,492 & 4,771 & 0,000 \\
\hline$(\mathrm{X} 2) \rightarrow(\mathrm{X} 3)$ & 0,099 & 0,582 & 0,561 \\
\hline$(\mathrm{X} 3) \rightarrow(\mathrm{Y})$ & 0,719 & 7,168 & 0,000 \\
\hline$(\mathrm{X} 1) \rightarrow(\mathrm{Y})$ & 0,033 & 0,467 & 0,641 \\
\hline$(\mathrm{X} 1) \rightarrow(\mathrm{Y})$ & 0,366 & 3,892 & 0,000 \\
\hline \multicolumn{5}{c}{ Tabel Indirect Effect } \\
\hline & $\begin{array}{c}\text { Original } \\
\text { Sample } \\
(\mathbf{O})\end{array}$ & $\begin{array}{c}\text { T- } \\
\text { Statistics }\end{array}$ & P Values \\
\hline$(\mathrm{X} 2) \rightarrow(\mathrm{Y})$ & 0,071 & 0,544 & 0,587 \\
\hline$(\mathrm{X} 1) \rightarrow(\mathrm{Y})$ & $-0,263$ & 3,532 & 0,000 \\
\hline
\end{tabular}

Nilai koefisiensi Ukuran Perusahan (X1) terhadap Profitabilitas (X3) sebesar 0,366 dengan signifikansi nilai T-Statistik sebesar 3,892> 1,960 (nilai T-tabel) dan $\mathrm{P}$-value $0,000<0,05$. Maka dapat disimpulkan $\mathrm{H}_{1}$ diterima dan $\mathrm{H}_{0}$ ditolak. Maka ukuran perusahaan berpengaruh terhadap profitabilitas.

Nilai koefisien Leverage (X2) terhadap Profitabilitas (X3) sebesar 0,099 dengan signifikansi nilai T-Statistik sebesar 0,582 < 1,960 (Nilai T-Tabel) dan P-Value 0,561 > 0,05. Dapat isimpulkan $\mathrm{H}_{0}$ diterima dan $\mathrm{H}_{1}$ ditolak. Maka leverage tidak berpengaruh terhadap profitabilitas.

Nilai koefisien Profitabilitas (X3) terhadap Nilai Perusahaan (Y) sebesar 0,719 dengan signifikansi nilai T-Statistik sebesar 7,168 > 1,960 (nilai T-table) dan P-Value sebesar 0,000 < 0,05. maka dapat disimpulkan $\mathrm{H} 1$ diterima dan $\mathrm{H} 0$ ditolak. Maka profitabilitas berpengaruh terhadap nilai perusahaan.

Nilai koefisien Ukuran Perusahaan (X1) terhadap Nilai Perusahaan (Y) sebesar 0,033 dengan signifikansi nilai T-Statistik sebesar 0,467 < 1,960 (nilai T-tabel) dan P-Value sebesar 0,641 > 0,05. maka dapat disimpulkan $\mathrm{H} 0$ diterima dan $\mathrm{H} 1$ ditolak. Maka ukuran perusahaan tidak berpengaruh terhadap nilai perusahaan.

Nilai koefisien Leverage (X2) terhadap Nilai Perusahaan (Y) sebesar 0,492 dengan signifikansi nilai T-Statistik sebesar 4,771 > 1,960 (Nilai TTabel) dan P-Value $0,000<0,05$. maka dapat 
disimpulkan $\mathrm{H} 1$ diterima dan $\mathrm{H} 0$ ditolak. Maka leverage berpengaruh terhadap nilai perusahaan

Nilai keofisien ukuran perusahaan (X1) terhadap nilai perusahaan (Y) melalui profitabilitas (X3) sebesar -0,263 dengan signifikansi nilai tstatistik sebesar 3,532>1,960 (nilai t-tabel) dan nilai p-value sebesar $0,000<0,05$. Berarti H1 diterima dan $\mathrm{HO}$ ditolak. Maka profitabilitas mampu memediasi pengaruh ukuran perusahaan terhadap nilai perusahaan.

Nilai keofisien leverage (X2) terhadap nilai perusahaan (Y) melalui profitabilitas (X3) sebesar 0,071 dengan signifikansi nilai t- statistik sebesar $0,544<1,960$ (nilai t-tabel) dan nilai $p$-value sebesar 0,071<0,05. Yang berarti H0 diterima dan H1 ditolak. Maka profitabilitas tidak mampu memediasi pengaruh leverage terhadap nilai perusahaan.

\section{Ukuran Perusahaan berpengaruh signifikan terhadap Profitabilitas}

Perusahaan yang lebih besar akan relative stabil dan mampu menghasilkan profit. Perusahaan dengan ukuran besar memiliki sumber daya yang besar dengan kegiatan operasional yang besar juga sehingga secara langsung menunjukan bahwa perusahaan memiliki potensi yang besar dalam mendapakan keuntungan yang besar pula. Penelitian ini sejalan dengan dengan hasil penelitian Laksiaputri (2012) yang menyatakan bahwa ukuran perusahaan berpengaruh terhadap profitabilitas. Dengan semakin besarnya ukuran perusahaan, maka perusahaan memiliki sumber daya dan asset untuk mendapatkan keuantungan.।

\section{Leverage tidak bepengaruh signifikan terhadap Profitabilitas}

Hal ini berarti peningkatan leverge tidak akan menurunkan profitabilitas perusahaan secara signifikan. Ini mengidentifikansikan bahwa sebagian besar perusahaan yang menjadi sampel dalam penelitian ini lebih banyak menggunakan sumber dana dari dalam perusahaan dari pada dana pinjaman, sehingga besar kecilnya jumlah hutang yang dimilki oleh perusahaan tidak akan berpengaruh pada besar kecilnya profitabilits yang di peroleh perusahaan. Hasil penelitian ini sejlan dengan hasil penelitian Sari dan Asiah (2016).

\section{Profitabilitas berpengaruh signifikan terhadap Nilaia Perusahaan}

Semakin tinggi profitabilitas yang dimiliki oleh perusahaan, maka akan mencerminkan tingkat efisiensi perusahaan yang tinggi juga, sehingga terlihat kinerja perusahaan yang baik pula. Perusahaan yang memiliki profitabilitas yang tinggi akan meningkatkan kepercayaan investor sehingga mendapatkan dana yang cukup dan selanjutkan perusahaan dapat meningkatkan kinerjanya yang berakibat pada meningkatnya nilai perusahaan.
Hasil penelitian ini sejlan dengan hasil penelitian Setiadewi dan Purbawangsa (2015) yang menyatakan bahwa semakin mampu perusahaan menghasilkan laba, maka nilai perusahaan akan naik yang terlihat dari kenaikan harga sahamnya.

\section{Ukuran Perusahaan tidak berpengaruh signifikan terhadap Nilai Perushaan}

Ukuran perusahaan yang besar belum bisa menjamin nilai perusahaannya tinggi, karena perusahaaan besar mungkin belum berani melakukan investasi baru terkait dengan ekspansi, sebelum kewajiban-kewajibannya (hutang) sudah terlunasi. Di sisi lain, dalam menanamkan modal investor tidak hanya memandang ukuran perusahaan akan tetapi masih banyak faktor-faktor lain yang menjadi pertimbangan investor dalam menyalurkan dananya. Hasil penelitian sejalan dengan hasil penelitian Cheryta dkk (2016) yang menyatakan bahwa ukuran perusahaan yang lebih besar kemungkinan akan mengalami semakin besar dan masalah semakin kompleks, yang bisa menurunkan nilai perusahaan.

\section{Leverage berpengaruh signifikan terhadap Nilai Perusahaan}

Penggunaan hutang dapat meningkatkan nilai perusahaan sejauh penggunaan hutang memberikan manfaat dan tidak berada di atas nilai optimal. Keputusan manajemen perusahaan dalam penggunaan hutang merupakan sinyal yang diberikan terhadap investor untuk menilai prospek perusahaan. Perusahaan dengan prospek yang baik akan memilih untuk menggunakan hutang sebagai alternatif pendanaan dibandingkan dengan pendanaan dengan ekuitas luar. Hasil penelitian sejalan dengan hasil penelitian Ernawati dan Widyawati (2015) yang menyatakan bahwa semakin besar suatu perusahaan menggunakan pendanaan dengan yang diperoleh dari hutang, maka semakin tinggi pula efektifitas perusahaan dalam menghasilakan laba sehingga dapat meningkatkan nilai perusahaan.

\section{Profitabilitas memediasi Pengaruh Ukuran Perusahan Terhadap Nilai Perusahaan}

Ukuran perusahaan dapat menentukan nilai perusahaan melalui keuntungan yang diperoleh oleh perusahaan. Perusahaan besar pada umumnya dapat melakukan ekspansi pasar. Dan menunjukkan keberhasilan dalam mengembangkan bisnis, kemapanan dalam menjalankan perusahaan serta memiliki prospek yang baik. Sehingga membuat investor tertarik untuk ikut berinvestasi pada perusahaan tersebut. Meningkatnya keuntungan perusahaan membuat nilai perusahaan juga ikut naik karena prospek usaha yang sangat menyakinkan dan membuat harga saham perusahaan naik. Hasil penelitian ini sejalan dengan haisl penelitian Istamarwati dan Suseno (2017) 
Profitabilitas tidak mampu Memediasi Pengaruh Leverage terhadap Nilai Perusahaan

Pengaruh langsung leverage terhadap nilai perusahaan lebih besar $(0,492)$ dibandingkan pengaruh tidak langsung melalui profitabilitas (0,071). Sehingga profitabilitas tidak mampu memediasi pengaruh leverage terhadap perusahan. Hal ini berarti dengan adanya tambahan variabel profitabilitas atau kemampuan memperoleh laba tidak mempengaruhi leverage dalam meningkatkan nilai perusahaan. usaha yang sangat menyakinkan dan membuat harga saham perusahaan naik. Hasil penelitian ini sejalan dengan haisl penelitian Pratama dan Wiksuana (2016).

\section{PENUTUP}

\section{Kesimpulan}

Berdasarkan hasil penelitian, maka dapat disimpulkan sebagai berikut :

Hasil pengujian hipotesis menunjukan bahwa ukuran perusahaan berpengaruh signifikan terhadap profitabilitas. Hasil pengujian hipotesis menunjukan bahwa leverage tidak perngaruh signifikan terhadap profitabilitas. Hasil pengujian hipotesis menunjukan bahwa profitabilitas bepengaruh signifikan terhadap nilai perusahaan. Hasil pengujian ukuran perusahaan tidak berpengaruh signifikan terhadap nilai perusahaan. Hasil pengujian hipotesis menunjukan bahwa leverage berpengaruh terhadap nilai perusahaan. Hasil pengujian hipotesis menunjukan bahwa profitabilitas mampu memediasi pengaruh ukuran perushaan terhadap nilai perusahaan. profitbilitas tidak mampu memediasi pengaruh leverage terhadap nilai perusahaan

\section{DAFTAR PUSTAKA}

Brigham, Eugene F. dan Joel F. Houston (2012) Dasar-dasar Manajemen Keuangan. Terjemahan oleh Ali Akbar Yulianto. Jakarta : Salemba Empat

Cheng, Ming Chang \& Tzeng, Zuwei Ching. (2011). " The Effect of Leverage on Firm Value and How The Firm Financial Quality Influence on This Effect". World Journal of Management. 3(2)

Cheryta, Aldea Mita, Moeljadi dan Nur Khusniyah Indrawati. (2017). " The Effect of Leverage, Profitability, Information Asymmetry, Firm Size on Cash Holding and Firm Value of Manufacturing Firms Listed at Indonesian Stock Exchange". International Journal of Research in Business Studies and Management, 4(4)

Dewi, Ayu S Mahatma dan Ary Wirajaya. (2013). "Pengrauh Struktur Modal Dan Profitabilitas Dan Ukuran Perusahaan
Pada Nilai Perusahaan”. E-Jurnal Akuntansi Universitas Udayana. 4(2).

Ernawati, Dewi dan Dini Widyawati. (2015). "Pengaruh Profitabilitas, Leverage Dan Ukiran Perusahaan Terhadap Nilai Perusahaan". Jurnal Ilmu \& Riset Akuntansi. 4( 4).

Firmansah, Arif. (2017). “ Pengaruh Ukuran Perusahaan Dan Profitabilitas Terhadap Nilai Perusahaan Melalui Kebijkan Deviden “. Jurnal Ilmu dan Riset Manajemen. 6(1)

Hansen, Verawati dan Juniarti. (2014). "Pengaruh Family Control, Size, Sales Growth Dan Leverage Terhadap Profitabilitas Dan Nilai Perusahaan Pada Sector Perdagangan Jasa Dan Investasi”. Business Accounting Review. 2(1)

Harjito, Agus dan Martono. (2014). Manajemen Keuangan. Edisi Kedua Cetakan Kedua. Yogyakarta : EKONISIA

Harmono. (2011). Manajemen Keuangan : Berbasis Balanced Scorecard. Jakarta : Bumi Aksara

Hery. (2015) Analisis Kinerja Manajemen, Jakarta : PT. Grasindo

Hery. (2017). Kajian Riset Akuntansi. Jakarta : PT. Grasindo

Istamarwati dan Y. Djoko suseno. (2017). "Pengaruh Ukuran Perusahaan Dan Debt To Equity Ratio Terhadap Nilai Perusahaan Dengan Profitabilitas Sebagai Variabel Intervening". Jurnal Manajemen Sumber Daya Manusia. 11(1)

Jariah, Ainun. (2016). "Likuiditas, Leverage, Profitabilitas Pengrauhnya Terhadap Nilai Perusahaan Manufaktur Di Indonesia Melalui Kebijkan Deviden”. Jurnal Riset Akuntansi dan Keungan Indonesia. 1(2)

Kasmir. (2012(. Analisis Laporan Keuangan. Jakarta : PT. Raja Grafindo Persada

Laksitaputri, Iriena Maharani. (2012). “ Analisis Factor-Faktor Yang Memepengaruhi Nilai Perusahaan Dengan Profitabilitas Sebagai Variabel Intervening". Jurnal Bisnis Strategi. 21 (2).

Limbong, Dita T. Sampriani, Mochammad Chabachib. (2016). “ Annalisis Pengaruh Struktur Modal, Pertumbuhan Penjualan Dan Ukuran Perusahaan Terhadap Nilai Perusahaan Dengan Profitabilitas Sebagai Variabel Intervening”. Dipoenogoro Journal Of Management, 5(4)

Murhadi, Werner R. (2013). Analisis Laporan Keuangan, Proyeksi dan Valuasi Saham. Jakarta : Salemba Empat

Noor, Juliansyah. (2017). Metodologi Peneltian : Skripsi, Tesis, Disertasi dan Karya Ilmiah, Cetakan Ke-17. Jakarta : Kencana

Pratama, I Gusti B. A dan I Gusti Bagus Wiksuana. (2016). "Pengaruh Ukuran Perusahaan dan 
Leverage Terhadap Nilai Perusahaan Dengan Profitabilitas Sebagai Variabel Mediasi “. E-Jurnal Manajemen Unud, Bali, 5(2)

Putri, Iriena Maharani. (2012). "Analisis Faktor Factor Yang Mempengaruhi Nilai Perusahaan Dengan Profitabilitas Sebagai Variabel Intervening., Jurnal Bisnis Strategi, 21(2)

Riduwan dan Sunarto. (2014). Pengantar Statistika untuk Penelitian : Pendidikan Sosial, Ekonomi dan Bisnis. Bandung : Alfabeta

Saebani, Beni Ahmad dan Kadar Nurjaman. (2013). Manajemen Penelitian. Bandung : CV Pustaka Setia

Sartono, Agus. (2010). Manajemen Keuangan Teori dan Aplikasi. Edisi. Keempat. Yogyakarta : BPFE

Sugiyono. (2015). Metode Penelitian Pendidikan : Pendekatan Kuantitatif, Kualitatif dan $R \& D$. Cetakan Ke-21. Bandung : Alfabeta

Suryani dan Hendryadi. (2016). Metode Riset Kuantitatif: Teori Dana Aplikasi Pada Peneltian Biadang Manajemen dan Ekonomi Islam. Jakarta : Prenadamedia

Sutrisno. (2013). Manajemen Keuangan: Teori, Konsep dan Aplikasi. Yogyakarta: EKONISIA
Profil Penulis :

1. Ayu Octaviany, Universitas Bina Bangsa Banten, Jl. Raya Serang - Jakarta Km. 03 No.1B Pakupatan Kota Serang - Banten

Email : ayuoctaviany_01@yahoo.com

2. Syamsul Hidayat, Universitas Bina Bangsa Banten, Jl. Raya Serang - Jakarta Km. 03 No.1B Pakupatan Kota Serang - Banten Email : masteryah@gmail.com

3. Miftahudin, Universitas Bina Bangsa Banten, J1. Raya Serang - Jakarta Km. 03 No.1B Pakupatan Kota Serang - Banten Email : masteryah@ymail.com 